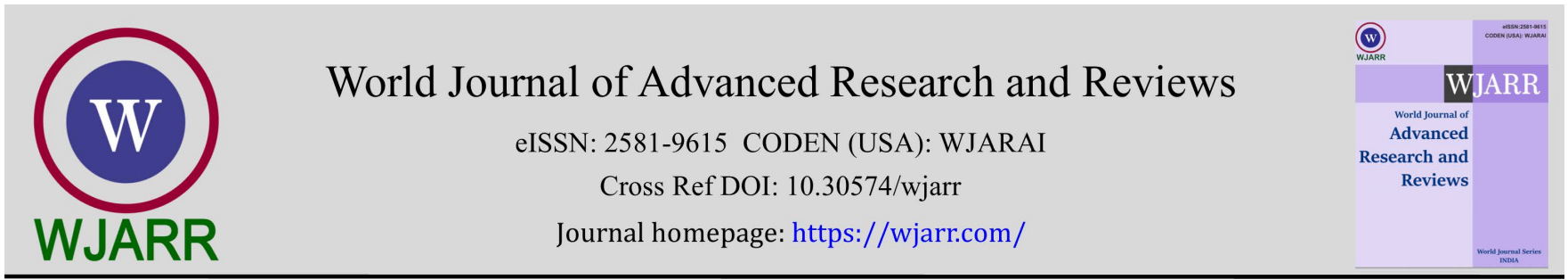

(RESEARCH ARTicle)

Check for updates

\title{
Evaluate the financial efficiency of semi-intensive prawn farming: A case study in My Xuyen district, Soc Trang province
}

\author{
Nguyen Quoc Nghi 1,*, Bui Van Trinh ${ }^{2}$ and La Nguyen Thuy Dung 1 \\ ${ }^{1}$ Can Tho University, Vietnam \\ 2 University of Cuu Long, Vietnam
}

World Journal of Advanced Research and Reviews, 2021, 12(02), 478-482

Publication history: Received on 14 October 2021; revised on 21 November 2021; accepted on 23 November 2021

Article DOI: https://doi.org/10.30574/wjarr.2021.12.2.0612

\begin{abstract}
Semi-intensive prawn farming is currently facing difficulties in both the production and consumption processes. Climate change and an unstable output market are the main causes affecting the investment efficiency of semi-intensive prawn farming. The authors carry out the study to evaluate the financial efficiency of semi-intensive prawn farming in My Xuyen District, Soc Trang Province. Research data are collected from 100 households raising prawns. The research results show that, with an average investment cost of 19.8 million VND/1000m2/crop, farmers may earn a profit of 6.5 million VND/1000m2/crop, and the profit margin achieved reaches 0.25 times. Therefore, the model of semi-intensive prawns achieves high financial efficiency and brings a great income for prawn farmers.
\end{abstract}

Keywords: Financial efficiency; Semi-intensive; Prawn; Farmer

\section{Problem statement}

Currently, semi-intensive prawn farming has attracted farmers in My Xuyen District, Soc Trang Province. Accordingly, this type of model gradually affirms its effectiveness and provides a high source of income for farmers. However, the model still faces many obstacles in both production and consumption. The difficulties and challenges come from both objective and subjective reasons (Nghi, 2014). Several common challenges are climate change, epidemic, environmental pollution, increasing prices of inputs, and unstable output markets. Furthermore, most households raising prawns in My Xuyen District have little access to market information and not much attention to farming techniques. To evaluate the financial efficiency of semi-intensive prawn farming, there should be authentic and scientific evidence. Therefore, this study is conducted to provide helpful information for the local agricultural industry and farmers participating in the semi-intensive prawn farming model.

\section{Research methodology}

Research data: To ensure the representativeness of research data, the quota sampling method is used to collect primary data. Grouping criteria include production area and farming scale. The study applies direct interviews to collect data from 100 farmers participating in the semi-intensive prawn farming model. The farmers live in six communes of My Xuyen District, including Hoa Tu 1, Ngoc To, Gia Hoa 1, Ngoc Dong, Thanh Phu, and Hoa Tu 2.

Analytical method: Descriptive statistical method is used to evaluate the status of semi-intensive prawn farming and the market accessibility of households in My Xuyen District. Besides, financial ratios such as revenue, cost, profit, profit margin are included to assess the financial efficiency of the farming model.

\footnotetext{
${ }^{*}$ Corresponding author: Nguyen Quoc Nghi

School of Economics, Can Tho University, Vietnam.

Copyright (C) 2021 Author(s) retain the copyright of this article. This article is published under the terms of the Creative Commons Attribution Liscense 4.0.
} 


\section{Research results and discussion}

\subsection{Characteristics of farmers}

The survey results show that the average age of prawn farmers is relatively high (about 45 years old). The average number of experience years is over 15 years. Meanwhile, the level of education of farmers is still low (about grade 7 or grade 8). In the field of agricultural production, especially prawn farming, most of the workers are low-skilled. Their production is mainly based on experiences and farming habits. This partly affects the access to the market trend and application of new techniques in prawn farming. The number of farmers directly raising prawns is smaller than the number of people in the family. This number reaches two farmers per household, while the average number of members in a family is five people/household. Due to the labor attraction from non-agricultural fields or the young workforce traveling for working or studying, the direct labor source for prawn farming in the study area tends to be increasingly scarce. According to the survey results, the average water surface area for each household's semi-intensive prawn farming is $10,853 \mathrm{~m} 2$. Some households expand the production area to 45,000 $\mathrm{m} 2$. The gap in prawn farming areas in the district is quite large, with a standard deviation of 7,669.91 $\mathrm{m} 2$.

Table 1 Characteristics of farmers

\begin{tabular}{|c|c|c|c|c|c|}
\hline Criteria & Unit & Min & Max & Mean & Standard deviation \\
\hline Household head's age & Year & 21 & 73 & 45.26 & 10.68 \\
\hline Number of school years & Year & 0 & 15 & 7.50 & 3.43 \\
\hline Number of experience years in prawn farming & Year & 2 & 35 & 15.28 & 5.99 \\
\hline Number of family members & Person/household & 2 & 9 & 4.73 & 1.34 \\
\hline Number of direct labors & Person/household & 1 & 4 & 1.71 & 0.72 \\
\hline Area of water surface for prawn farming & $1.000 \mathrm{~m} 2$ & 2,000 & 45,000 & 10,853 & $7,669.91$ \\
\hline
\end{tabular}

\subsection{Production characteristics}

Table 2 Production characteristics

\begin{tabular}{|l|c|c|}
\hline Criteria & Frequency (Farms) & Percentage (\%) \\
\hline 1. Number of farming crops in one year \\
\hline 1 crop/year & 66 & 66 \\
\hline 2 crop/year & 34 & 34 \\
\hline 2. Participate in training courses \\
\hline No & 64 & 64 \\
\hline Yes & 36 & 36 \\
\hline 3. Participate in cooperatives \\
\hline No & 87 & 87 \\
\hline Yes & 13 & 13 \\
\hline 4. Demand for loans & 60 \\
\hline No & 60 & 40 \\
\hline Yes & 40 & \\
\hline
\end{tabular}


As recommended by the local agricultural industry, to increase the productivity of prawns, farmers should raise one crop/year (the seasonal schedule may last from mid-March to mid-August), according to a study by Nghi et al. (2010). The survey results show that most prawn farming households in My Xuyen District raise only one crop/year (accounting for 66\%), the remaining 34\% raise two crops/year. The majority of farmers raise prawns following their personal experiences (accounting for 64\%). The number of fa rmers applying techniques provided in training sessions by feed or chemical companies accounts for 36\%. Few farmers participate in cooperatives (accounting for 13\%), the number of semi-intensive prawn farmers not participating in cooperatives accounts for $87 \%$. The percentage of farmers who demand loans to invest and expand production scale is relatively high, accounting for $60 \%$. This reflects the reality of the "thirst for capital" situation of aquafarming, especially semi -intensive prawn farming in My Xuyen District.

The analysis result in table 3 says that the market access ability of semi-intensive prawn farmers is low. For the input market, farmers have easy access to feed and farming drugs (with a score of more than 4.00/5.00). The reason is the input market is very diverse. Meanwhile, the source of prawn seed is a factor that farmers consider hard to access (mediate level). Moreover, most farmers find it difficult to access information on farming equipment. The ability to approach output agents such as traders, seafood granaries, or seafood companies is at an average level. Besides, farmers' understanding level about purchasing traders is still low (average score of 2.51/5.00). The main cause is that farmers cooperate with one buyer only, rarely exploit information and seek output markets.

Table 3 Households' market accessibility

\begin{tabular}{|c|c|c|c|c|c|}
\hline Criteria & Unit & Min & Max & Mean & Standard deviation \\
\hline \multicolumn{6}{|c|}{ Input market } \\
\hline Breed & \multirow{4}{*}{$\begin{array}{l}\text { Ascending from } 1 \text { to } \\
5: 1 \text { means very bad, } 5 \\
\text { means very good }\end{array}$} & 1 & 5 & 3.36 & 0.772 \\
\hline Feed & & 2 & 5 & 4.01 & 0.692 \\
\hline Drug & & 2 & 5 & 4.00 & 0.696 \\
\hline Equipment & & 1 & 5 & 2.29 & 0.701 \\
\hline \multicolumn{6}{|c|}{ Output market } \\
\hline Trader & \multirow{3}{*}{$\begin{array}{l}\text { Ascending from } 1 \text { to } \\
5: 1 \text { means very bad, } 5 \\
\text { means very good }\end{array}$} & 2 & 5 & 2.51 & 0.782 \\
\hline $\begin{array}{l}\text { Seafood } \\
\text { granary }\end{array}$ & & 1 & 5 & 2.97 & 0.822 \\
\hline Company & & 2 & 4 & 2.83 & 0.753 \\
\hline
\end{tabular}

Semi-intensive prawn farmers have plenty of different sources to access market information. In particular, the channel from acquaintances is most commonly accessed (53\%). Market information from media is also popular (42\%). However, most prawn farmers believe that information from the media is for market price reference only. The fact shows that raw prawns' price at prawn ponds is significantly different from the price announced on market channels. Prawn buyers are also an important information channel for farmers (farmer proportion accessing the market trend through buyer's accounts for 34\%). The remaining farmers access market information through feed agents, chemical drug agents, agricultural extension officers, etc.

\subsection{Evaluate the financial efficiency}

Based on the analysis result, feed costs account for the highest proportion $(43.32 \%)$ in the total cost structure of farmers. This is an essential input factor, which greatly affects the growth rate of prawns. If farmers chose high-quality feed, prawns would grow quickly, have good disease resistance, and get a high yield (Nghi, 2013). Therefore, feed is the factor that farmers pay the most attention to and invest in the most. The actual survey proves that feed is a "burden" of farmers because the price of feed is high and fluctuates according to the market. This leads to the high cost of feed for prawns. The second-highest proportion of the cost is family labor cost (26.09\%). One of the features of semi-intensive prawn farming activities in household models is the investment in care and management to minimize potential production risks. Therefore, farmers should invest in family labor for prawn farming. Also, the farm drug cost accounts for $12.61 \%$ of the cost structure. The epidemic is an objective factor that greatly influences the productivity and profitability of prawn farming. The risk of epidemics is always a concern of most prawn farmers. Therefore, to prevent 
and reduce the impacts of diseases on prawn productivity, farmers spend a lot on farming medicine. The remaining costs include seed cost, water treatment cost, equipment cost, fuel cost, and some other costs.

Table 4 Financial efficiency of semi-intensive prawn farming in My Xuyen District

\begin{tabular}{|l|c|c|c|}
\hline Criteria & Mean & Standard deviation & Percentage (\%) \\
\hline 1. Breed cost & $1,553.16$ & $1,234.82$ & 7.84 \\
\hline 2. Water treatment cost & $1,151.62$ & $1,066.92$ & 5.82 \\
\hline 3. Feed cost & $8,578.10$ & $6,362.22$ & 43.32 \\
\hline 4. Farming medicine cost & $2,498.03$ & $2,118.54$ & 12.61 \\
\hline 5. Fuel cost & 293.45 & 327.44 & 1.48 \\
\hline 6. Hired labor cost & 34.18 & 303.77 & 0.17 \\
\hline 7. Family labor cost & 5.167 .74 & $4,658.03$ & 26.09 \\
\hline 8. Harvest and transportation cost & 85.02 & 173.99 & 0.43 \\
\hline 9. Equipment cost & 412.57 & 387.44 & 2.08 \\
\hline 10. Tool cost & 29.27 & 89.99 & 0.15 \\
\hline 11. Others & 0.89 & 7.88 & 0.01 \\
\hline 12. Total cost & $19,804.02$ & $11,478.72$ & 100.00 \\
\hline 13. Revenue & $26,266.72$ & $23,013.22$ & - \\
\hline 14. Profit & $6,462.70$ & $16,115.70$ & - \\
\hline 15. Profit margin (time) & 0.25 & 0.27 & - \\
\hline
\end{tabular}

According to the analysis, the average revenue achieved by semi-intensive prawn farmers is 26.3 million VND/1000m2/crop. With an average investment cost of 19.8 million VND/1000m2, farmers may earn about 6.5 million $\mathrm{VND} / 1000 \mathrm{~m} 2 / \mathrm{crop}$. The average profit margin of the household is 0.25 times. The investment time for a semi-intensive prawn crop lasts for six months, compared to the average interest rate of banks in the same period, the profit rate achieved is high. Thus, in terms of financial efficiency, semi-intensive prawn farming models in My Xuyen District show good results. In the future, if farmers focus on improving farming methods, using technical advances, and proactively approaching the market to limit production risks, prawn farming models will develop sustainably and become a strength of the locality.

\section{Conclusion}

In general, the financial efficiency of semi-intensive prawn farming models in My Xuyen District is relatively high. This type of model can bring profits, increase income, and improve the lives of local farmers. Besides objective risks, farmers' market access has limitations that have certain influences on the financial performance of prawn farming. With the current situation, the local authority should pay more attention and build support programs in terms of market access, capital, and techniques to help farmers improve production resources and investment efficiency in the future.

\section{Compliance with ethical standards}

\section{Acknowledgments}

The researchers appreciated all the corrections suggested and recommended by the experts. Special thanks to the respondent farmers for their cooperation and participation during the research. This research received no precise funds from any agency in the public or private sectors. 
World Journal of Advanced Research and Reviews, 2021, 12(02), 478-482

\section{Disclosure of conflict of interest}

The authors declare that there are no competing or potential conflicts of interest

\section{References}

[1] Nghi NQ. Analyze the production efficiency of industrial prawn farming households in Chau Thanh District, Tra Vinh Province. Seafood Trade Magazine. 2013; 166: 82-84.

[2] Nghi NQ. Demand for agricultural insurance of prawn farming households in Mekong Delta. Banking Science \& Training Review. 2014; 170: 28-33.

[3] Nghi NQ, Trinh BV, Truyen HM. Factors affecting productivity and profit of prawn farming households in Tra Vinh Province from 2008 to 2009. Science and Technology Journal of Agriculture and Rural Development. 2010; 16: 53-57. 